\title{
走查プローブ顕微鏡を用いたナノ・スクラッチ試験 による高分子表面の構造・物性解析
}

\section{1.はじめに}

近年，薄膜や表面，異種材料界面など，原子や分子の運 動をナノ領域内で制限することで非平衡状態を誘起し，そ の高いエネルギー状態を利用して特異な構造や物性を得よ うとする試みが行われている。このような非平衡状態では 階層構造が形成されやすく，これがナノ材料が特異な物性 を発現する要因の一つとなっている，例えば，非晶性高分 子の最表面の分子鎖は運動性が高いため，バルクよりもガ ラス転移温度が低下することが知られている ${ }^{1), 2)}$. 同様に, 高分子材料表面の機械的特性もバルク状態と大きく異なる と予想されるが，表面領域の物質量は少ないため，これら を解析する手段は限られている。

我々は，走査プローブ顕微鏡（SPM）の探針を高分子 フィルム表面に押し付け，これを摺動させることで， $\mathrm{nm}$ レベルの傷付き試験を行い，その結果から，高分子材料表 面の変形特性を見積もるとともに，表面から内部にかけて の階層構造形成や表面層の分子配向性を評価してきた．本 稿では，いくつかの高分子材料にこの「SPM ナノ・スク ラッチ試験」を適用した結果を元に，nm レベルでの高分 子材料表面の傷付き特性を検討した事例を紹介する。

\section{2，SPM ナノ・スクラッチ試験}

高分子材料表面に対する SPM ナノ・スクラッチは, 1992 年に Leung $ら^{3)}$ により初めて行われた。図 1 に，我々 が行っている標準的なナノ・スクラッチ試験の方法を示し た。まず，探針（先端径 $30 \mathrm{~nm}$ 程度）を $\mathrm{nN}$ オーダーの任 意の荷重（5～100 nN）で試料表面に押し当て，この状態 で，カンチレバーに対して垂直方向（図 1 では左右方向） に $1 \mu \mathrm{m}$ 幅で走査する.これをカンチレバーに対して垂直 方向に少しずつ移動させながら，通常 256 回（2の乗数回） の走査を行うことで $1 \mu \mathrm{m} \times 1 \mu \mathrm{m}$ の領域をまんべんなく スクラッチする (1 st スクラッチ)。走査速度は通常，0.5 $\mathrm{Hz}$ から数 $\mathrm{Hz}$ 程度である.

この $1 \mathrm{st}$ スクラッチ後に，測定範囲を $1.5 \mu \mathrm{m} \times 1.5 \mu \mathrm{m}$ に拡大し， 2 nd スキャンを行う。この時は，荷重をなる

\footnotetext{
* Uehara, Hiroki/Yamanobe, Takeshi 群馬大学理工学研究院分子科学部門 桐生市天神町 1-5-1（ ₹ 606-8585） hirokiuehara@gunma-u.ac.jp 2013.4. 16 受理
}

上 原 宏 樹* · 山 延

健*
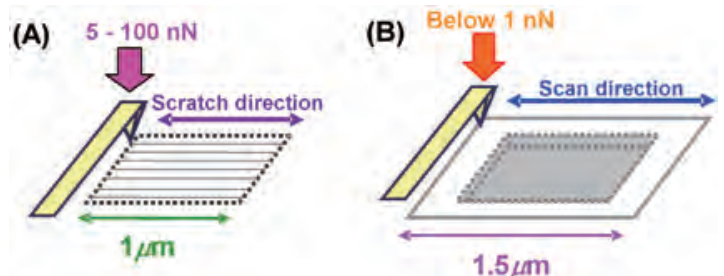

図 $1 \mathrm{SPM}$ ナノ・スクラッチ試験の概略. $1 \mu \mathrm{m} \times 1 \mu \mathrm{m}$ の スクラッチ（A）後に, $1.5 \mu \mathrm{m} \times 1.5 \mu \mathrm{m}$ で形状観 察（B）を行う. カンチレバーに印加する荷重は 5 〜 $100 \mathrm{nN}$ で変化させる.

ベくかけず，スクラッチにより形成された形状を観察する. スラッチ領域（1 $\mu \mathrm{m} \times 1 \mu \mathrm{m} ）$ を中央にして，スクラッチ していない外側部分も同一画像内に記録することで，スク ラッチ前後での形状変化（例えば，掘り込み深さや磨耗粉 の量など）を数值的に解析することができる.

ナノ・スクラッチ試験のパラメーターとしては，荷重， スクラッチ（走査）回数，スクラッチ周波数，スクラッチ 方向等が挙げられるが，荷重を変えてスクラッチ像を記録 し，これらを比較することで，材料最表面から内部にかけ ての機械特性の変化を見積もるのが一般的である．荷重が 小さい場合は最表面層の，また，荷重が大きいときは，よ り深い領域の機械特性の情報が得られる.どの程度の深さ 領域に対応しているかは，断面プロファイルによって確認 することができる．また，スクラッチ方向を変化させれば, 対応する深さ領域での分子配向性を見積もることができる.

ナノ・スクラッチ試験に供する試料表面は平滑であるこ とが好ましい。なぜなら，試料表面に凹凸があると，しば しば，これを強調したナノ・スクラッチ像が得られてしま うからである。特に周期的な凹凸パターンが初めから材料 表面に存在する場合，この初期凹凸に起因したナノ・スク ラッチ・パターンを，対象高分子特有の分子特性（分子鎖 の剛直性や配向性）や相構造（結晶構造や結晶性）と誤認 してしまうことがある。したがって，ナノ・スクラッチ前 の試料形状を把握しておくことは極めて重要である.

\section{3.ポリスチレン ${ }^{4}$}

高分子材料は非常に長い鎖状の分子形態を有するために, 分子鎖同士が「絡み合う」という点が低分子量の有機材料 や金属材料と大きく異なる点である．このような分子鎖絡 み合いは，一定以上の分子量で発生し，この分子量は臨界 
絡み合い分子量 $\left(M_{c}\right)$ と定義されている. この臨界分子 量以上では, 高分子材料特有の粘弾性挙動が発現するとと もに，破断強度が急激に上昇する.SPMナノ・スクラッ チ試験による表面傷付き挙動は, $\mathrm{nm}$ レベルの破壊現象で あるため，このような分子量依存性が強く発現すると予想 される。このようなナノ・スクラッチ挙動の分子量依存性 を調べるために，対象試料としてポリスチレン（PS）を 選択した. PSは分子量測定の標準物質に用いられており, 様々な分子量かつ単分散（分子量分布がほほ 1 ）の試料が 市販されている。 そこで, PSの $M_{c}$ である $30,000^{5}$ を挟ん だ分子量 8,000（8k）から 984,000（984k）までの5つ の単分散試料を溶液キャストして厚さ数 $\mu \mathrm{m}$ の平滑フィ ルムを作製し，そのSPMナノ・スクラッチ挙動を比較し た. 図 2 は，これらのフィルム表面を荷重 $10 \mathrm{nN}$ でスク ラッチして得られた形状像である。 これを見ると, 分子量 $8 \mathrm{k}$ と $15.8 \mathrm{k}$ では，スクラッチ領域にパターンは認められ ず，均一に掘り込まれていることがわかる，また，最終ス クラッチ・ライン（スクラッチ領域の最下部）の外側に白 く写った盛り上がり領域が観察されている。この盛り上が り領域は，再度スキャンすると分子量 $8 \mathrm{k}$ の場合のように, 他の部分にも移動していたことから，スクラッチによって 発生した磨耗粉であることがわかる. 一方, 分子量 $58 \mathrm{k}$ 以上では，このような磨耗粉は一切観察されず，代わりに， スクラッチ領域内に特徵的な周期パターンが発生している ことがわかる. この周期パターンの形状は, 再スキャンし てもまったく変化していないので，磨耗粉に起因するもの でない.このような周期構造形成は crack-opening 現象( によって形成されると考えられておりり，PSのガラス転移 温度が室温以上であるためにスクラッチにより試料表面に 周期的に亀裂が入り，これが探針の移動によって拡大する ことで特有の凹凸パターンが形成されると解釈されている. 周期構造の大きさは $\mu \mathrm{m}$ レベルであるものの, 同様のク ラックが通常の摩擦試験（荷重数 Nレベル）を行った PS

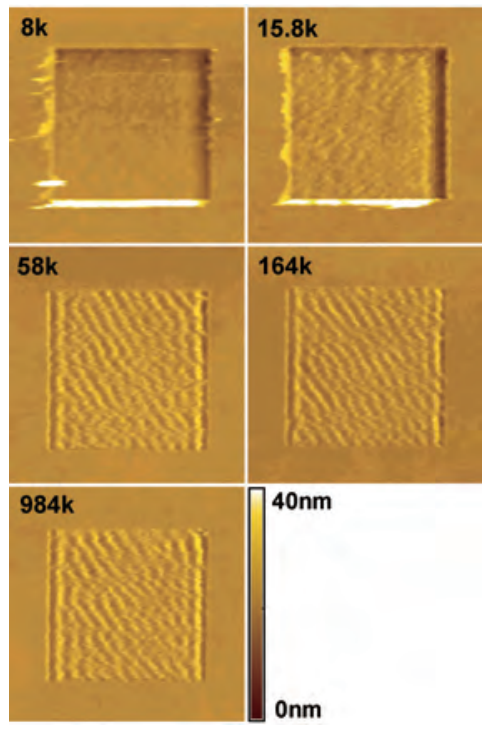

図 2 分子量の異なる単分散 PS のキャストフィルムのナ ノ・スクラッチ像. 分子量 8,000 (8k) 984,000 $(984 \mathrm{k})$ についての結果を比較した. スクラッチ領 域は $1 \mu \mathrm{m} \times 1 \mu \mathrm{m}$. 印加荷重は $10 \mathrm{nN}$. スクラッチ 方向は左右方向.
フィルム表面でも観察されており7)，このようなスケール を超えた平面変形挙動の類似性は興味深い.

これら磨耗粉を発生させる低分子量 PS と周期構造を与 える高分子量 PS をブレンドした場合, いずれかのスク ラッチ・パターンが優勢となっていれば，フィルム表面で の分子量の偏析が起こっていることがわかる. そこで， $M_{c}$ 以下の分子量 $8 \mathrm{k}$ の PS と Mc 以上の分子量 $164 \mathrm{k}$ の PS を 様々な比率で混合してキャスト・フィルムを調製し, その ナノ・スクラッチ試験を行った。図 3 に荷重 $10 \mathrm{nN}$ でス クラッチした結果を示した. これを見ると，スクラッチ後 の形状像は, 低分子量成分 $(8 \mathrm{k})$ が増えるにつれて, 周 期構造が徐々に不明瞭になり, 磨耗粉の発生量が増大して いることがわかる。このような周期構造から磨耗粉発生へ の連続的な変化は，荷重を変えてスクラッチした場合も同 様であった。これらのことから, 非晶性高分子である PS では, フィルム表面での分子量の偏析は起こらないと言える.

\section{4. ポリエチレン8}

これに対して, 結晶性高分子ブレンド系ではナノ・スク ラッチ挙動が大きく異なる。まず，最も一般的な結晶性高 分子であるポリエチレン (PE) について，ナノ・スクラッ 于挙動の分子量依存性を検討した. $\mathrm{PE}$ の場合, 単分散か つ高分子量の試料が市販されていないので，メ夕ロセン系 触媒で合成された分子量分布の狭い試料を用いた。図 4 に, 高分子量フィルム（分子量：583,000）と低分子量フィル 厶（分子量：110,000）のナノ・スクラッチ変形挙動を比 較した. 結晶性高分子の場合, 溶液キャスト後の乾燥時に フィルム表面に結晶化に起因する凹凸が形成されてしまう

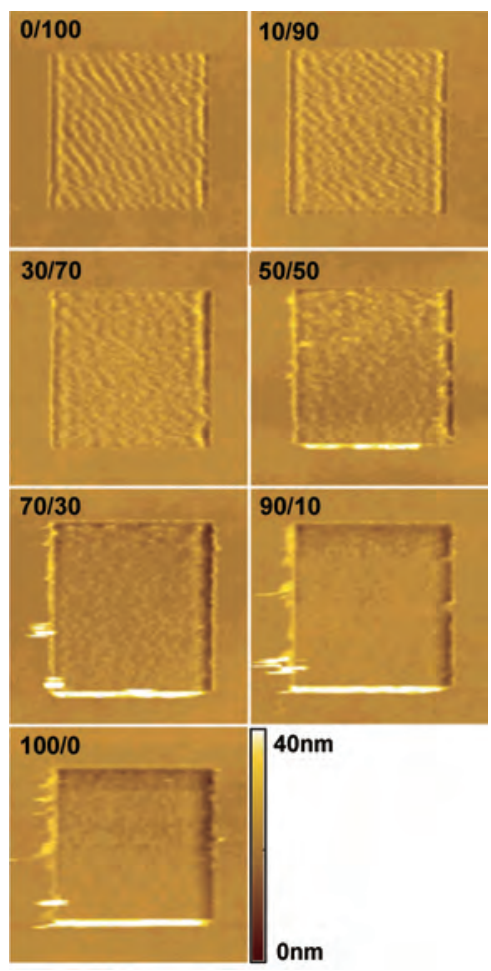

図 3 低分子量 PS（15.8 k） と高分子量 PS（164 k）のブ レンドフィルムのナノ・スクラッチ像. $15.8 \mathrm{k} / 164$ kのブレンド比率が示してある. スクラッチ領域は $1 \mu \mathrm{m} \times 1 \mu \mathrm{m}$. スクラッチ荷重は $10 \mathrm{nN}$. 
ので，融点以上の $180^{\circ} \mathrm{C}$ でプレス成形を行って平滑表面を 有する PEフィルムを得た。なお，このプレス成形時の溶 融保持時間を 1 分〜 6 時間で変化させた. 図 4 から，分子 量や溶融保持時間に関わらず，PE 表面のナノ・スクラッ チでは，フィブリル状のパターンが得られており，PS 表 面のような周期構造は形成されないことがわかる.これら のことは, 結晶性高分子では, ナノ・スクラッチ過程で分 子配向が起こることを示唆している．このような分子配向 は, 通常の摩擦試験後の PE 表面でも観察されており ${ }^{9}$, 特に高分子量 PE が優れた摺動特性（低摩擦係数）を示す 原因となっている.

高分子量フィルムの表面形状像では，溶融保持時間に関 わらず，スクラッチ領域の端に摩耗粉は現れていない。こ こで断面プロファイルを切り出すことによりフィルム表面 の掘りこみ深さを計測すると, 溶融保持時間 5 分 (A) お よび 3 時間（B) ともに, 深さ約 $30 \mathrm{~nm}$ まで掘りこまれてい ることが分かった.このことより,この溶融保持時間範囲で はフィルム表面の分子量低下は起こっていないと考えられ る.一方, 低分子量フィルムの表面形状像 (C)では, スク ラッチ領域の端に摩耗粉の堆積が観察された。 また, 断面 プロファイルから見積もった掘りこみ深さも $50 \mathrm{~nm}$ 以上 と高分子量フィルムよりも大きくなっていた. これらのこ とは, 摩耗粉の有無と掘りこみ深さによって低分子量 $\mathrm{PE}$ 表面と高分子量 PE 表面が区別できることを意味している.

次に, PS 同様に分子量ブレンドがナノ・スクラッチ変 形挙動に及ぼす効果を検討するため, これら異なる分子量 を有する PE 試料を様々な比率（低分子量：高分子量）で 溶液混合してブレンド試料を調製し，これをさらにプレス 成形してブレンドフィルムを得た。図 5 は 50 : 50 ブレン ドフィルムについて，プレス成形時の溶融保持時間を 1 分 〜3 時間として作製した $50 ： 50$ ブレンドフィルムのナ ノ・スクラッチ後の形状像を比較したものである. 溶融保 持時間に関係なく，どのフィルム表面でもスクラッチ領域 の端に摩耗粉が現れていることがわかる.これは図 4 で示 した低分子量フィルムの表面変形挙動とよく一致している. このことから 50：50ブレンドフィルムの表面には低分子 量成分が偏析していると言える.

さらに $25: 75$ ブレンドフィルムに対してもナノ・スク ラッチ試験を行ったところ，50：50ブレンドフィルムと 同様, 全ての溶融保持時間において摩耗粉の堆積が確認で きた。しかし，同一保持時間 1 時間で比較をすると，高分 子量成分の多い $25 ： 75$ ブレンドフィルムでは, $50 ： 50$ ブ レンドフィルムに比べて, 掘り込み深さが小さかった.
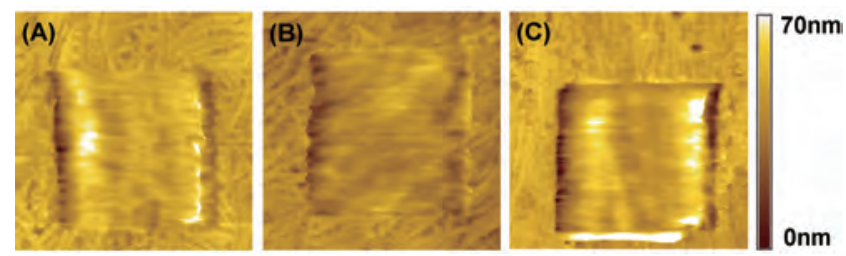

図 4 高分子量 PE（A，B）および低分子量 PE（C) フィ ルムのナノ・スクラッチ像. スクラッチ領域は $1 \mu \mathrm{m}$ $\times 1 \mu \mathrm{m}$. スクラッチ荷重は $30 \mathrm{nN}$. スクラッチ方向 は左右方向. (A) の溶融保持時間は 5 分, (B) と （C）は 3 時間でフィルムを作製した.
10：90 ブレンドについても，断面プロファイルより掘り こみ深さを計測し，これらの值を溶融保持時間に対してプ ロットしたところ, 図 6 のようになった。図中の赤い点線 は低分子量フィルムの掘りこみ深さ, 緑の点線は高分子量 フィルムの掘りこみ深さを表しており，溶融保持時間に依 存せず,ほぼ一定であった.これを見ると, 50 : 50 ブレンド フィルムでは溶融保持時間の増加に伴って掘りこみ深さが 増大し，次第に低分子量フィルムの值に近づいていってい ることがわかる。これらの結果は，ブレンドフィルムの表 面では, 溶融保持時間の増加に従って低分子量成分のフィ ルム表面への偏析が進行することを示唆している。一 方, $25: 75$ ブレンドフィルムにおいては, 溶融保持時間が 短い場合は掘り込み深さの変化は小さいものの, 溶融時間 1 時間を越えたあたりから急激に掘り込み深さが上昇し, 溶融保持時間 3 時間で調製したフィルムでは低分子量フィ ルムの掘りこみ深さに近い值となった。しかしながら，さ らに高分子量成分の多い $10 ： 90$ ブレンドフィルムでは, 溶融保持時間 6 時間まで長くしても, 掘り込み深さがほと んど変化していなかった.このことは, 高分子量成分が多く なると，これをすり抜けて低分子量成分が表面偏析してく るのに時間がかかることを示唆している．前述したように， このような表面層への低分子量成分の偏析は PS では確認
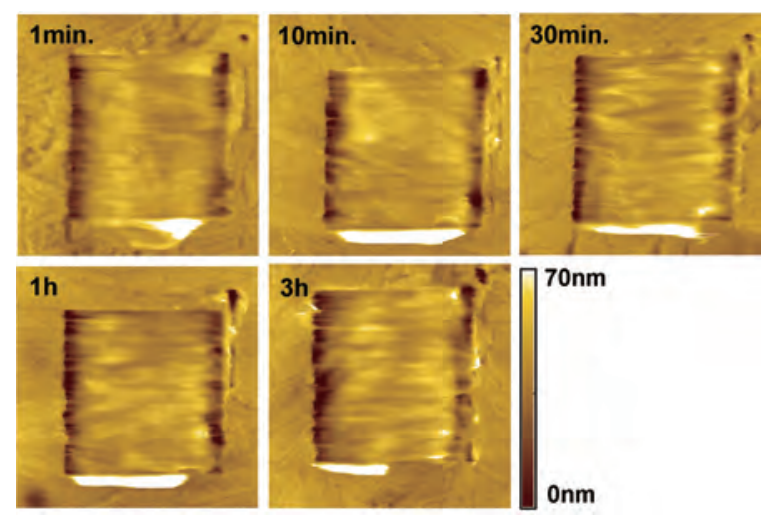

図 5 低分子量 PE と高分子量 PE の 50 ：50 ブレンドフィ ルムのナノ・スクラッチ像. 図中の時間は溶融保持 時間. スクラッチ領域は $1 \mu \mathrm{m} \times 1 \mu \mathrm{m}$. スクラッチ 荷重は $30 \mathrm{nN}$. スクラッチ方向は左右方向.

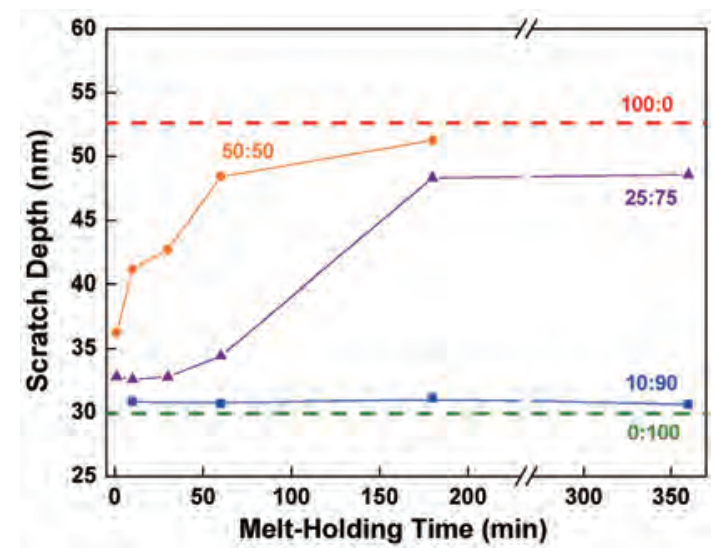

図 6 溶融保持時間に対する平均掘り込み深さ（荷重 30 nN）の関係. 図中の数値は低分子量 PE：高分子量 PE の比率. 低分子量のみ $(100 ： 0)$ および高分子 量のみ $(0 ： 100)$ の值が点線で示してある. 
されておらず, 結晶化がこの低分子量成分のブリード・アウ 卜現象に大きな影響を及ぼしていることが明らかとなった。

\section{5.ポリ乳酸10)}

ポリ乳酸（PLA）は, 再生可能資源から生産可能であ るため, 脱化石燃料化および炭素固定化が図れると期待さ れている環境低負荷型生分解性高分子である.このポリ乳 酸の結晶構造は成形条件によって異なり, 特にL 体 PLA (PLLA）とD体 PLA（PDLA）のブレンドによって発現 するステレオコンプレックス晶 (Sc 晶) の融点は $220^{\circ} \mathrm{C}$ と, 通常の PLLA 及び PDLA 単品から形成される $\alpha$ 晶 $\left(170^{\circ} \mathrm{C}\right)$ よりも顕著に高く ${ }^{11)}$, その耐熱性や耐加水分解性 ${ }^{12)}$ が注目されている.

そこで, 同程度の分子量（約 230,000）を有する PLLA と PDLAを 50：50の比率で溶液キャストしてブレンド

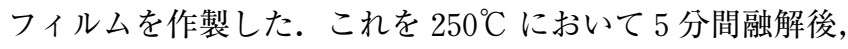
プレス成形し, さらに液体窒素中に投入して急冷フィルム を作製した。 また，同様にキャストフィルムを $250^{\circ} \mathrm{C}$ で溶 融プレス後, $100^{\circ} \mathrm{C}$ および $150^{\circ} \mathrm{C}$ に冷却して 1 時間, 等温 結晶化させたフィルムを作製した。これらプレス成形後の 各フィルムについて, ゲルろ過クロマトグラフィー測定を 行なって試料分子量を確認したところ, どのフィルムも原 料の分子量が維持されていた.

まず,これら結晶化条件の異なるフィルムのナノ・スク ラッチ後のフィルムの形状像を比較した(図 7).急冷フィ ルムのスクラッチ像 $(\mathrm{A})$ では, スクラッチ領域内部で周期 的な構造が観察されている.この現象は前述した非晶性高 分子であるPSフィルムのナノ・スクラッチ結果と類似して いる.斜入射 X 線回折測定 (GIXD)の結果からも, 表面領域, バルク領域ともに非晶状態であることが確認できた.

一方, 比較的低い温度 $\left(100^{\circ} \mathrm{C}\right)$ で結晶化させたフィル 厶（B）を見ると（A）のような周期構造は観察されず， 結晶化によって表面変形が抑制されることを示唆している. このフィルムのナノ・スクラッチ試験を荷重を変えて行 なったところ, どの荷重においても元々存在していたラメ ラ構造に起因するモルフォロジーが観察されていた. GIXD 測定の結果もこの結果とよく一致しており, 表面領 域, バルク領域ともに $\alpha$ 晶由来の回折プロファイルが得 られ，結晶化度も約 $40 \%$ でほぼ同じであった。これらの ことは, PLAの $\alpha$ 晶はスクラッチしても分子配向しにく いことを示している.

これに対して，150 C で結晶化させたフィルム (C) で は, 殆ど変形していない部分が存在することがわかる。こ

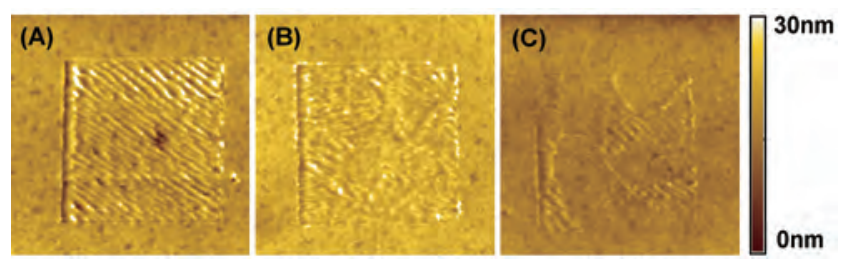

図 7 PLLA : PDLA=50：50 ブレンドフィルムのナノ・ スクラッチ像.（A）急冷フィルム, (B) $100^{\circ} \mathrm{C}$ 結 晶化フィルム, (C) $150^{\circ} \mathrm{C}$ 結晶化フィルム. スクラッ チ領域は $1 \mu \mathrm{m} \times 1 \mu \mathrm{m}$. スクラッチ荷重は $30 \mathrm{nN}$. スクラッチ方向は左右方向.
のような硬さの異なる構造の共存は, 荷重を変えて得られ たナノ・スクラッチ像においても確認できた.このフィル ムの GIXD 測定結果は, Sc 晶が存在していることを示し ており，特に表面領域で Sc 晶の含有割合が増加していた. これが, $150^{\circ} \mathrm{C}$ 結晶化フィルムの表面変形が抑制されてい た原因であると推測される。

\section{6. 配向 PET フィルム ${ }^{13}$}

前述したように，高分子に特有の分子鎖「絡み合い」は バルク物性だけでなく，ナノ・スクラッチ挙動にも大きな 影響を与えていた。 そこで, 鎖状の分子構造がもたらすも う一つの特徵である分子鎖の「異方性」についても，ナノ・ スクラッチ挙動への影響を検討した。

ここで，分子配向させたフィルムを調製する方法として， 延伸法が挙げられるが, PEのような高結晶性材料を延伸 すると配向結晶化により数 $\mu \mathrm{m}$ 幅のマクロ・フィブリル が形成されてしまうため，平滑表面にならない欠点がある. そこで, 結晶性が低く, かつ, 高延伸が可能なポリエチレ ンテレフタレート（PET）を試料として選択した。実際， 延伸によって製造された PET 配向フィルムは, ディスプ レー等に用いる偏向材料として広く用いられている.

まず，原料である固有粘度 $0.5 \mathrm{~g} / \mathrm{dl}$ （分子量 18000 に相 当）の低分子量 PET を融点以下の $220^{\circ} \mathrm{C}$ で 36 時間, 減 圧することで固相重合し, 固有粘度 $0.8 \mathrm{~g} / \mathrm{dl}$ の高分子量

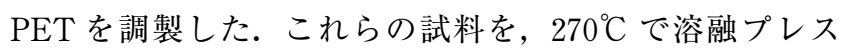

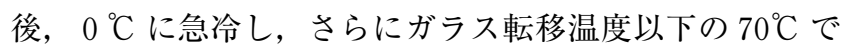
延伸比約 5 倍に一軸延伸して, 配向フィルムを調製した. この配向フィルムの延伸方向に対して平行方向 $\left(0^{\circ}\right.$ 方向 $)$ および垂直方向 $\left(90^{\circ}\right.$ 方向）に，ナノ・スクラッチを行っ た. まず, 低分子量 PET の配向フィルムのナノ・スクラッ チ結果（図 8）を見ると, 低荷重においても表面破壊に起 因する摩耗粉がスクラッチ領域の外周部に観察されている ことがわかる. また, $0^{\circ}$ 方向, $90^{\circ}$ 方向ともに，スクラッ チ方向に対してほぼ垂直に周期構造が現れていた.これら のナノ・スクラッチ挙動は, 前述の PS 表面に類似してお り，分子鎖の配向方向への異方性は確認できなかった.

一方, 高分子量 PET の配向フィルム（図 9）では, 高 荷重においても低分子量フィルムで観察された摩耗粉が認 められないことから, 分子量の増加に伴い, 表面の機械的 強度も向上していると言える。ここで, $0^{\circ}$ スクラッチで は, 荷重の上昇に伴って, 延伸方向に対して平行に溝の入っ たフィブリル状組織が発現している.このスクラッチ条件 において，スクラッチ回数を $256 \rightarrow 128 \rightarrow 64 \rightarrow 32 \rightarrow 16$ と減 少させたところ, スクラッチ後に得られた形状像ではスク ラッチ回数に対応した本数の溝が観察された. 従って, こ のようなフィブリル状組織は, 探針がフィルム表面を延伸 方向に沿って引き裂くことによって形成されることが明ら かとなった。

これに対して，90スクラッチにおいては，低荷重から 明瞭に周期構造が現れており，0スクラッチにおけるフィ ブリル状組織とは大きく異なっている. 同様の周期構造が 低分子量 PET 配向フィルム（図 8）でも観察されている ことを考えると, この特異な変形構造の発現は, フィルム 表面領域における分子鎖の移動に起因していると考えられ 


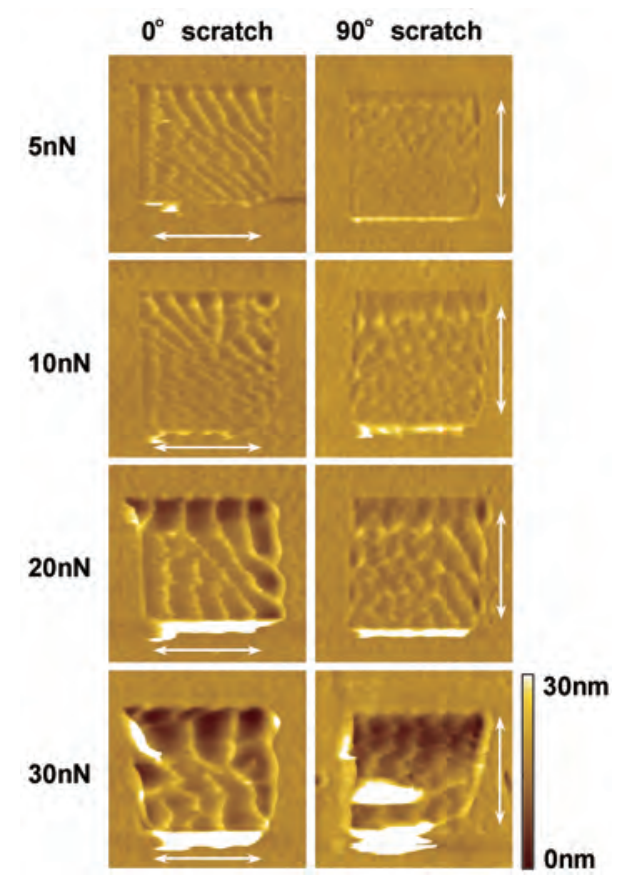

図 8 低分子量 PET 配向フィルムのスクラッチ荷重依存 性. スクラッチ領域は $1 \mu \mathrm{m} \times 1 \mu \mathrm{m}$. 矢印はフィル ムの延伸方向. スクラッチ方向は左右方向.

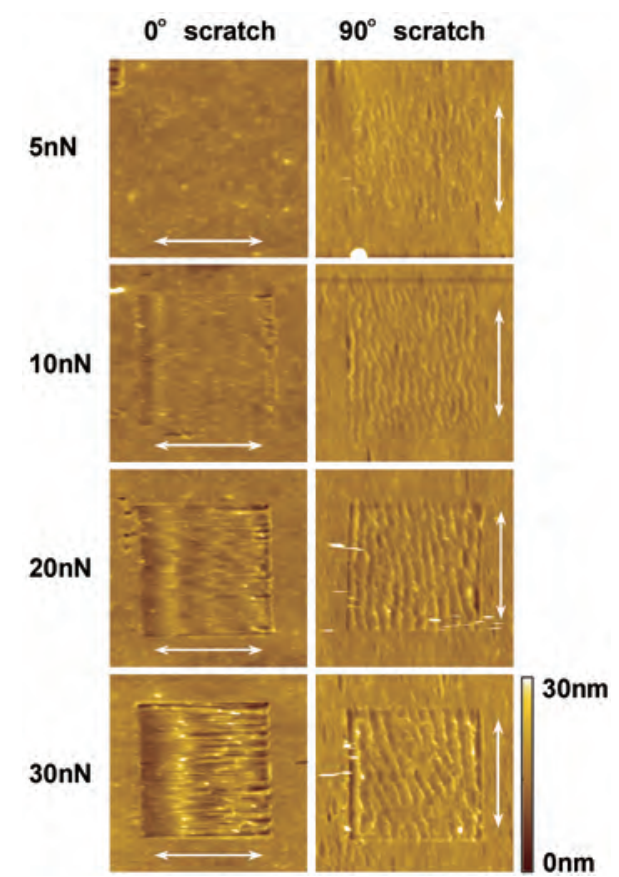

図 9 高分子量 PET 配向フィルムのスクラッチ荷重依存 性. スクラッチ領域は $1 \mu \mathrm{m} \times 1 \mu \mathrm{m}$. 矢印はフィル ムの延伸方向. スクラッチ方向は左右方向.

る.これは, 前述の PS 表面における周期構造の形成メカ ニズムとは全く異なっている.

このような表面変形挙動をバルク状態での変形挙動と比 較するため, 試料フィルムの引張り試験を行ったところ, $0^{\circ}$ 方向では, 高い降伏応力を示し, 低歪みで破断に至ってい るのに対して，90方向では，降伏応力が低く，かつ，降 伏後にネック変形が進行するため, 極めて大きな破断伸び を示していた.このことは, バルク状態においても, 延伸方 向と垂直方向に分子鎖が変形しやすいことを意味している.
以上のことにより，高分子量 PETを $0^{\circ}$ スクラッチし た場合，分子鎖方向の変形応力の方が分子鎖間のファンデ ルワールスカよりも大きいため, フィブリル状組織が発現 すると考えられる。一方， $90^{\circ}$ スクラッチで周期構造が発 現するのは，配向分子鎖が垂直方向に移動しやすいためで あり，その降伏応力が小さいことに起因して，低荷重から 表面変形が起こると解釈される.

\section{7.おわりに}

本稿では, $\mathrm{nm}$ レベルの傷付き特性からフィルム最表面 の構造を評価するSPM ナノ・スクラッチ試験法を各種高 分子材料表面に適用した事例を紹介した。荷重依存性から は階層構造化に関する情報が，また，スクラッチ角度依存 性からは分子配向性に関する情報が得られる。これら $\mathrm{nm}$ レベルでの機械物性は, バルク材料を対象とした通常の 引っ張り試験では評価することのできない指標である．今 後, MEMS 等の高度化によって高分子部材のさらなる微 小化が要請されると予想され，これら SPMナノ・スク ラッチ試験による材料最表面の機械特性の解析が各種のナ ノ材料設計にも貢献できると期待される。

\section{謝辞}

本稿の内容は, 青池卓氏 (現・三菱樹脂), 澤井大輔氏 (現・富士フィルム), 摚上将規氏 (現・埼玉大学), 浅川 達樹氏（現・JSR）, 諏訪純一氏（現・凸版印刷）による 研究成果をまとめたものです。なお，本研究の一部は NEDO 産業技術研究助成事業によって行われました.

\section{参 考 文 献}

1 ) Forrest, J. A., Dalnoki-Veress, K., Stevens, J. R. and Dutcher, J. R. : Phys. Rev. Lett., 77, 2002 (1996)

2 ) Tanaka, K., Takahara, A. and Kajiyama, T. : Macromolecules, 30, 6626 (1997)

3 ) Leung, O. M., Goh, M. C. : Science, 255, 64 (1992)

4 ) Aoike, T., Yamamoto, T., Uehara, H., Yamanobe, T. and Komoto, T. : Langmuir, 17, 5688(2001)

5 ) Graessley, W. W. : Adv. Polym. Sci., 16, 1(1974)

6 ) Elkaakour, Z., Aimé, J. P., Bouhacina, T., Odin, C. and Masuda, T. : Phys. Rev. Lett., 73, 3231 (1994)

7 ) Aoike, T., Uehara, H., Yamanobe, T. and Komoto, T. : Langmuir, 17, 2153(2001)

$8)$ Suwa, J., Kakiage, M., Yamanobe, T., Komoto, T. and Uehara, H. : Langmuir, 23, 5882 (2007)

9 ) Komoto, T. and Hironaka, S. : Angew. Makromol. Chem., 150, 189 (1987)

10) Kakiage, M., Ichikawa, T., Yamanobe, T., Uehara, H. and Sawai, D. : ACS Appl. Mater. Interfaces, 2, 633 (2010)

11) Ikada, Y., Jamshidi, K., Tsuji, H. and Hyon, S. -H. : Macromolecules, 20, 904 (1987)

12) Tsuji, H. : Polymer, 41, $3621(2000)$

13) Uehara, H., Asakawa, T., Kakiage, M., Yamanobe, T. and Komoto, T. : Langmuir, 22, 4985 (2006) 